\title{
Defining the Crime of Enforced Disappearance in Conformity with International Criminal Law: a New Frontier for Bangladesh
}

\author{
MD. RAISUL ISLAM SOURAV*
}

\section{Introduction}

Occurrences of abductions, kidnaps, enforced disappearances, and killings have increased dramatically in Bangladesh in the last few years. Among these, the case of seven murders allegedly perpetrated by high officials of the Rapid Action Battalion (RAB) ${ }^{1}$ at Narayanganj ${ }^{2}$ in 2014 has created most reaction among civil society such as lawyers, rights activist etc. in Bangladesh. Civil engagement exposed the cruelty and inhumanity of the incident and spread awareness about the gravity of these offences.

Most cases are unresolved to this day and very few abductees have been rescued successfully by law enforcement. However, in most of cases the victim's family members, relatives and friends targeted their allegations towards law enforcement agencies. Specific allegation have been made that individuals wearing civilian dress, but introducing themselves as members of the RAB, Detective Branch (DB) or of other law enforcement agencies are arresting and forcefully taking the victim with them. The detained person then

MD. Raisul Islam Sourav received his LL.B. (Hons) \& LL.M. degree from the Northern University Bangladesh (NUB); he currently works as an assistant professor \& coordinator at the department of law, Dhaka International University (DIU), Bangladesh and is an attorney before the Supreme Court of Bangladesh. He is also a law \& justice analyst, essayist, researcher, and rights activist. He writes newspaper articles on contemporary legal issues in Bangladesh. His recent article titled 'In Quest of a Legal Framework for Domestic Workers in Bangladesh' has been published in the Journal of Malaysian and Comparative Law in 2014.

1 A specialised battalion in charge of preventing terrorism and militancy in Bangladesh.

2 A district of Bangladesh situated near Dhaka.

This is an Open-access article distributed under the terms of the Creative Commons Attribution 3.0 Unported License (http://creativecommons.org/licenses/ by/3.0/, permitting all use, distribution, and reproduction in any medium, provided the original work is properly cited. 
typically vanishes from custody with none aware of their fate and whereabouts. Corpses were found in very few cases. When confronted with such allegations, law enforcement agencies deny any involvement. To date have few offenders been brought to justice. Such incidents are not properly investigated, and no visible action has been undertaken to prevent their reoccurrence.

It is however clear that the state has a responsibility to prevent such crimes and ensure the punishment of those responsible, failing which a culture of impunity will be allowed to bloom. The object of this paper is to scrutinise and analyse the socio-legal aspects of forced disappearances and to suggest a way towards the ratification of the UN Convention for the Protection of All Persons from Enforced Disappearance ('the Convention'). This would in turn improve the ability of the state to prevent the occurrence of such crime and to combat impunity.

This paper will present and contrast the definition of enforced disappearance in respectively national and international criminal law. The following section will assess the role of the Committee on Enforced Disappearance (CED), which is established by the Convention to monitor and evaluate the overall situation of forced disappearance in the state parties. This paper will also examine the impacts of enforced disappearances on the individual and on society as a whole. It will also be shown that the current situation amounts to a continuous violation of national and international customary law and that continued enforced disappearances constitute international crimes and crimes against humanity. Finally, some recommendations will be put forward to bring about an end to the situation.

\section{The emergence and definition of enforced disappearance in in- ternational criminal law}

Enforced disappearance is not new to international criminal law. Enforced disappearances persist in many countries, having been a continuing feature of the second half of the twentieth century since they were perpetrated on a mass scale in Nazi-occupied Europe. ${ }^{3}$ The crime of enforced disappearance of persons became first known when ${ }^{4}$ Adolf Hitler issued the 'Nacht und Nebel Erlass' (Night and Fog Decree). The decree directed that persons in occupied territories engaging in activities intended to undermine the security of German troops were, upon capture, to be brought to Germany 'by night and fog' for trial by special courts, thus circumventing military procedure and various conventions governing the treatment of prisoners. From the mid-1960s, disappearance as a tool of political repression was employed by security forces in Guatemala. It was from Guatemala

$3 \quad$ Henckaerts \& Doswald-Beck, Customary International Humanitarian Law (CUP 2005), p. 379. $4 \quad$ on December 7, 1941. 
that the term desaparecido (disappeared one) originated in the 1960s. In the 1970s, disappearances occurred in significant numbers in Argentina, Chile, Philippines and Uganda amongst other places. ${ }^{5}$

In Chile, the systematic practice of 'disappearances' lasted from 1973 to 1977, with about 1,300 missing. That is in addition to the 2,000 people who were killed outright in extra-judicial executions. Forced disappearances were also practice in Argentina on a much larger scale and lasted for four years, from 1976 to $1980 .{ }^{6}$

Enforced disappearance was first recognised as a human rights problem in the 1970s, when human rights lawyers in Chile noted that some of the prisoners they were representing had vanished even though they were ostensibly still held in custody by Chilean security forces. ${ }^{7}$

However, enforced disappearance has emerged as a critical problem at the national and international level. In the last decades, the international community has taken steps to combat enforced disappearances, both at the regional and international level, with the Declaration on the Protection of all Persons from Enforced Disappearance of $1992^{8}$, the Inter-American Convention on Forced Disappearance of Persons of $1994^{9}$, and the Rome Statute of the International Criminal Court of 1998. Following this expansion, the UN General Assembly adopted the International Convention for the Protection of All Persons from Enforced Disappearance in December 2006. ${ }^{10}$ The Convention entered into force on 23 December, 2010. To date, 90 states have become signatories, and 30 have ratified the Convention. ${ }^{11}$ Among state parties, 12 have recognized the competence of the Committee of Enforced Disappearances (CED) to receive and consider communications both by individuals alleging that their rights under the Convention have been violated as well as communications by states claiming that another state party is not fulfilling its obligations under the Convention. Very few states have so far implemented the Conven-

5 Amnesty International, Disappearances: A Workbook (AIUSA 1981), p.2.

$6 \quad$ Walling, Booth \& Waltz (ed.), Human Rights: From Practice to Policy, Proceeding of a research workshop (Gerald R. Fold School of Public Policy, University of Michigan 2010), available at: http://humanrightshistory.umich.edu/files/2012/07/Zalquette1.docx (Last accessed on 18 December 2015).

$7 \quad$ Ibid.

8 United Nations, General Assembly resolution 47/133, Declaration on the Protection of all Persons from Forced Disappearance, A/RES/47/133 (18 December 1992), available at http:// undocs.org/A/RES/47/133.

9 Popularly known as Inter-American Convention.

10 The text was adopted on 20 December 2006 (A/RES/61/177), and was opened for signature on 6 February, 2007.

11 The countries that have ratified the Convention to date are: Albania, Argentina, Armenia, Belgium, Bolivia, Brazil, Burkina Faso, Chile, Cuba, Ecuador, France, Gabon, Germany, Honduras, Iraq, Japan, Kazakhstan, Mali, Mexico, Montenegro, Netherlands, Nigeria, Panama, Paraguay, Senegal, Serbia, Spain, Tunisia, Uruguay \& Zambia. 
tion into national law. The convention aims at preventing enforced disappearances from taking place, uncovering the truth when they do occur, punishing the perpetrators and providing reparations to the victims and their families.

The Convention gives a definition of the crime of enforced disappearance and sets out which state action is necessary in order to prevent the occurrence of the crime, to allow for an effective investigation, and to lead to the prosecution of those responsible. In accordance with Article 2, an enforced disappearance takes place when a person is arrested, detained or abducted by the state or agents acting for the state, who then deny that the person is being held or conceal their whereabouts, placing them outside the protection of the law. The Convention identifies the following elements in the definition of enforced disappearances:

- There is an arrest, detention, abduction or any other form of deprivation of liberty;

- That conduct is carried out by agents of the state or by persons or groups of persons with the authorisation, support or acquiescence of the state;

- The conduct is followed either by a refusal to acknowledge the deprivation of liberty or by the concealment of the fate or whereabouts of the disappeared person;

- The objective result of the conduct is that the disappeared person is placed outside of the protection of the law.

Article 1(2) also provides that exceptional circumstances, such as a state or threat of war, internal political instability or any other public emergency, may not under any circumstances be invoked as a justification for enforced disappearance. Under Article 4 state parties also have an obligation to take necessary measures to ensure that enforced disappearance constitutes an offence under national criminal law.

Moreover, the aforementioned Convention in Article 6(1) also provides liability criteria for the offence of enforced disappearance. Under subparagraph (a), 'any person who commits, orders, solicits or induces the commission of, attempts to commit, is an accomplice to or participates in an enforced disappearance,' is liable. Subparagraph (b) extends liability to any superior who ' $k n e w$, or consciously disregarded information which clearly indicated- that subordinates under his or her effective authority and control were committing or about to commit a crime of enforced disappearance.'

Enforced disappearance is also a cumulative violation of human rights. ${ }^{12}$ This is because it may inflict a wide range of human rights violations, including the violation of:

- The right to life, as the person may be killed or his or her fate may be unknown, cf. Art. 32 of the Bangladeshi Constitution;

12 Ratner, Abrams \& Bischoff, Accountability for Human Rights Atrocities in International Law: Beyond the Nuremberg Legacy, 3rd ed. (OUP 2009), pp. 128-29. 
- The right to personal security and dignity;

- The right to be free from arbitrary detention, cf. Art. 33 of the Bangladeshi Constitution;

- The right not to be subjected to torture or other cruel, inhuman or degrading treatment or punishment, cf. Art. 35 of the Bangladeshi Constitution;

- The right to humane conditions of detention, cf. Art. 33 of the Bangladeshi Constitution;

- The right to legal personality, cf. Art. 31 of the Bangladeshi Constitution;

- The right to fair trial, cf. Art. 35 of the Bangladeshi Constitution;

- The right to free movement, cf. Art. 36 of the Bangladeshi Constitution;

- The right to family life;

All of the above rights are guaranteed as fundamental rights under the constitution and are either directly or indirectly applicable by Bangladeshi courts. ${ }^{13}$

The Rome Statute of the International Criminal Court particularly classifies forced disappearance as a crime against humanity, see Art. 7(1)(i).

For the crime of enforced disappearance to be committed under Article 7, the following elements must be present:

1. One or several persons have been arrested, detained, or abducted.

2. This deprivation of liberty was preceded, followed or accompanied by a refusal to acknowledge the deprivation of freedom or to give information on the fate or whereabouts of the victim(s).

3. Both 1) and 2) were carried out by, or with the authorization, support or acquiescence of an emanation of the state or a political organisation.

4. The perpetrator was aware of 1 ) and 2).

5. The intention was to remove the victim(s) from the protection of the law for a prolonged period of time.

6. The conduct was committed as part of a widespread or systematic attack directed against a civilian population.

7. The perpetrator knew that the conduct was part of such an attack.

In addition, the Inter-American Convention on the Forced Disappearance of Persons also imposes an obligation on state parties 'not to practice, permit or tolerate the forced disappearance of persons, even in the states of emergency or suspension of individuals guarantees', see Article 1(a).

As is shown, international law does not only consider enforced disappearances as a cruel crime and gross violation of human rights, it is also considered as a crime against 
humanity, where the state itself plays vital role behind the scenes. Any prevention mechanism must therefore be directed towards the state, something which is the purpose of the UN Convention. Combating enforced disappearances thus requires that Bangladesh ratifies the UN convention and adopts national legislation that criminalises enforced disappearances.

\section{The significance of the International Convention for the Protec- tion of All Persons from Enforced Disappearance}

Unlike other human rights violations, enforced disappearances were not considered specifically by a universal legally binding instrument before the Convention came into force in 2010. ${ }^{14}$ Before that only the Rome Statute of the International Criminal Court ${ }^{15}$ provided for the prosecution and the award of reparation to victims in cases where enforced disappearance amounted to a crime against humanity. ${ }^{16}$

However, the crime of enforced disappearances was prohibited prior to 2010 by the 1992 UN Declaration on the Protection of all Persons from Enforced Disappearance, the 1996 Inter-American Convention, as well as customary international humanitarian law. However, this previously existing framework exhibited serious gaps and ambiguities, and had proven to be insufficient as a protection mechanism. The Convention, despite its own flaws, corrects some of the existing gaps in the legal framework.

- Firstly, the Convention makes enforced disappearance a crime under international law, which is non-derogable even under exceptional circumstances, such as the state or threat of war, internal political instability or any other public emergency.

- Secondly, the Convention obliges states to criminalise Enforced Disappearances in national law.

- Thirdly, it enshrines the right of victims or their relatives to have access to justice and full and to full and effective reparation.

- Fourthly, the Convention sets up the Committee on Enforced Disappearances which began its work in November 2011.

Prior to the Convention's entry into force, the only mechanism dealing specifically with enforced disappearances was the UN Working Group on Enforced or Involuntary Disappearances. ${ }^{17}$ This Working Group, established by the 1992 Declaration, continues to exist and carries out important work as a rapid response mechanism to request states to start investigations where it is believed that an enforced disappearance has taken place,

14 Cassese, International Criminal Law, 2nd edition (OUP 2003), p. 80.

15 Came into force in 2002.

16 Meron, The Humanization of Humanitarian Law (Brill 2000), pp. 94 \& 239.

17 Berman \& Clark, State Terrorism: Disappearances, in 13 Rutgers Law Journal (1982), pp. 531 ff. 
based on reports of disappearances submitted by relatives of disappeared persons or human rights organisations acting on their behalf.

The Convention, in contrast to the 1992 Declaration or the regional conventions, goes further when defining the term 'victim'. A 'victim' under the Convention includes the abducted person as well as any individual who has suffered harm as the direct result of an enforced disappearance. This definition covers both direct and indirect victims and thus includes family members who ignore the whereabouts of their relative and can, therefore, be qualified as torture victims. ${ }^{18}$ It establishes, for the first time in a human rights treaty, the explicit right of each victim to know the truth regarding the circumstances of the enforced disappearance, the progress and results of the investigation, and the fate of the person who has disappeared.

Moreover, the Convention, contrary to the 1992 Declaration and human rights documents, also lists forms of reparation. The right to obtain reparation covers material and moral damages and, where appropriate, other forms of reparation such as:

a) Restitution;

b) Rehabilitation;

c) Satisfaction, including restoration of dignity and reputation;

d) Guarantees of non-repetition. ${ }^{19}$

These forms of reparation echo the provisions of General Assembly resolution A/ $\mathrm{RES} / 60 / 147 .^{20}$ This resolution emphasised the need for an effective remedy in cases of gross violations of international human rights law and serious violations of international humanitarian law. The resolution affirms the obligation on all states to investigate and, if there is sufficient evidence, the duty to prosecute the person allegedly responsible for the violations, and, if found guilty, the duty to punish the perpetrator. It also outlines obligations on states to cooperate with one another, and to assist international judicial organs competent in the investigation and prosecution of these violations.

States are encouraged to facilitate extradition, to surrender offenders to other states and to appropriate international judicial bodies, to provide judicial assistance, and to cooperate in the pursuit of international justice. This includes assisting and protecting victims and witnesses, consistently with international human rights legal standards and

Bazorkina v. Russia, appl. no. 69481/01, 27.07.2006, and Edriss El Hassy v. The Libyan Arab Jamahiriya, No. CCPR/C/91/D/1422/2005.

19 Article 24 of the Convention.

20 United Nations, General Assembly resolution 60/147, Basic Principles and Guidelines on the Right to a Remedy and Reparation for Victims of Gross Violations of International Human Rights Law and Serious Violations of International Humanitarian Law, A/RES/60/147 (16 December 2005), available at http://undocs.org/A/RES/60/147. (Last accessed on 18 December 2015) 
subject to international legal requirements such as those relating to the prohibition of torture. $^{21}$

Among other forms of effective reparation, the resolution includes the possibility of rehabilitation, which should include medical and psychological care, as well as legal and social services. It is noteworthy that the Convention also provides for access to rehabilitation. ${ }^{22}$ While other forms of reparation for human rights violations are provided for in all core UN human rights treaties, this form of reparation is a novelty in international human rights treaties and is currently only practiced by the Committee against Torture (CAT), which is responsible for monitoring the prevention of torture and other cruel, inhuman or degrading treatment.

The Committee on Enforced Disappearance (CED) can similarly receive requests for urgent action from relatives of the disappeared, their legal representatives or others, which it can transmit to the state party concerned with a request to clarify the fate and whereabouts of the disappeared person. It also competent to consider individual complaints by persons who claim to be the victim of a violation of the Convention, although this competence must be specifically recognised by the states. The Committee is also empowered to perform other functions to monitor the Convention's implementation and state parties' compliance with their obligations.

\section{The role of the committee on enforced disappearance (CED) to prevent forced disappearances}

The Committee on Enforced Disappearance (CED) is similar in form and function to other UN human rights treaty bodies, such as the Committee against Torture (CAT). The CED is composed of ten experts in the field of human rights, who serve on the Committee in their individual capacity and are expected to exercise their functions independently and impartially. Within two years of ratifying the Convention, state parties are required to submit a report to the Committee describing the measures they have undertaken to implement the Convention. After examining the report, the Committee makes general suggestions and recommendations to the state party as it considers appropriate. Furthermore, the Committee can transmit requests for urgent action sent by or on behalf of the relatives of a disappeared person to state parties requesting that they clarify the fate and whereabouts of the disappeared person. It can also undertake visits if it receives reliable information indicating that a state party is seriously violating the provisions of the

\footnotetext{
$21 \quad$ Ibid.

22 The possibility of rehabilitation was initially foreseen in the GA Resolution A/RES/60/147.
} 
Convention, and may bring situations of widespread or systematic practices of enforced disappearances to the attention of the UN General Assembly.

Moreover, the Committee also has an optional individual complaints system. It can under this system consider complaints submitted by or on behalf of individuals alleging to be victims of a violation of the provisions of the Convention by a state party, provided by the state has declared that it accepts the competence of the Committee to receive such individual communications. The Committee may also receive and consider communications in which one state party claims that another state party is not fulfilling its obligations under the Convention provided that both state parties concerned have agreed to the optional inter-state communications procedure.

\section{$5 \quad$ Effects of forced disappearances on societies and individuals}

Families are often emotionally unable to find closure and come to terms with the disappearance of their loved ones. Many suffer from severe psychological distress, sometimes resulting in physical illness as well. Children are not immune from such anguish; the disappearance of a parent, sibling or other members of the family often adversely affects their educational performance and social behaviour. ${ }^{23}$

Furthermore, families frequently face substantial economic consequences as a result of an enforced disappearance, particularly when the victim was the principal bread-winner of the family. Even if this was not the case, many families find themselves in a dire economic situation while they search for the victim. These families are then frequently isolated socially and culturally, with little support to fall back on. For example, while widows in certain cultures have a well-established support system within communities, wives of disappeared victims are at times left in a limbo. ${ }^{24}$

It is common for people who have disappeared never to be released, with their fate remaining unknown. But the person cannot simply have vanished. Someone surely knows what has happened to them. Someone is responsible, but all too often the offenders are never brought to justice. Nevertheless, the victim and their family have a right to justice and to receive reparations. ${ }^{25}$ They also have a right to know the truth about the circumstances of the enforced disappearance and the fate of the disappeared person, and the right to seek, receive and impart information to this end.

23 Amnesty International, Enforced Disappearances: Questions and Answers, 2011, p. 2. Available at: https://www.amnesty.org/en/documents/ior51/010/2011/zh/ (Last accessed on 18 December 2015)

24 UN War Crimes Commission, Law Reports of Trials of War Criminals, 1949, Volume I, p. 113.

25 van Schaack, Crimen sine Lege: Judicial Lawmaking at the Intersection of Law and Morals, in 97 Georgetown Law Journal (2008), pp. 97 \& 119. 


\section{Forced Disappearance under the criminal laws of Bangladesh}

Enforced, involuntary or forced disappearance is not a crime or offence under Bangladeshi law. Involuntary disappearance is however a domestic crime when it may considered as a crime against humanity under Article 7(1)(i) of the Rome Statute. Thus, unless the act fits the Rome statute's definition the state has sole jurisdiction to prosecute the perpetrator. However, enforced disappearances have taken place to a large extent since last couple of years in Bangladesh. Nevertheless the provisions pertaining to kidnapping and abduction in the Penal Code of 1860 may be applicable. ${ }^{26}$

According to section 362 of the Penal Code, a person is said to commit the offence of abduction when he by force compels or by any deceitful means induces another person to go from one place to another.

Kidnapping as defined by section 359 classifies two types of offences, namely kidnapping from Bangladesh and kidnapping from lawful guardianship. Whoever carries any person beyond the borders of Bangladesh without the consent of that person, or of some person legally authorised to consent on their behalf, is said to kidnap that person from Bangladesh. On the other hand, whoever takes or entices any minor or any person of unsound mind, out of the keeping of their lawful guardian is said to kidnap that person from guardianship.

The punishment for kidnapping is up to seven years' imprisonment and a fine. Where the kidnapping is undertaken with the intention to murder however, the prison sentence can be increased to ten years or to life imprisonment, pursuant to section 364 .

An analysis of the outlined criminal provisions can be summarised as follows:

- Kidnapping is committed when the victim is a minors under sixteen years of age in case of a male or under eighteen years in case of a female, or a person of unsound mind. The crime of abduction is independent of the age of the victim.

- In the event of a kidnapping, a minor is usually taken away, forcefully or not, without the consent of legal guardian. Force, compulsion or deceit are however basic elements of abduction.

- The consent of the minor is immaterial in cases of kidnapping, whereas in cases of abduction, the absence of consent is of vital importance.

- Kidnapping moves the victim away from the custody of legal guardian and being so it is a substantive offence, as opposed to abduction.

In addition to the above, if a person kidnaps or abducts any child under the age of ten, in order for the child to be murdered or to be subjected to grievous harm, slavery, or to 
sexual abuse; the penalty is death or life imprisonment or imprisonment for a term of between seven and fourteen years. ${ }^{27}$ Additionally, if a person kidnaps or abducts a woman in order for her to be compelled to marry someone against her will, or in order for her to be forced or seduced to have intercourse; the punishment is death, or life imprisonment, or imprisonment between ten and twenty years as well as a fine. ${ }^{28}$

The punishment for murder after an abduction is death or life imprisonment, pursuant to section 302 of the Penal Code. In addition to this, if the kidnapping or abduction is committed with an intention to forcible confinement, the punishment is a prison term of up to seven years and a fine.

\section{$7 \quad$ Violations of national and international laws}

The frequent allegations of involuntary disappearances betray that the rule of law is failing in Bangladesh. The Republic is under an obligation to safeguard every citizen's right to life and property. It also has the responsibility to protect citizens' fundamental rights as guaranteed by the Constitution. ${ }^{29}$ By detaining individuals without due process, the government of Bangladesh grossly violates a number of its citizens' fundamental rights.

The Constitution states that

to enjoy the protection of the law, and to be treated in accordance with law, and only in accordance with law, is the inalienable right of every citizen, wherever he may be, and of every other person for the time being within Bangladesh, and in particular no action detrimental to the life, liberty, body, reputation or property of any person shall be taken except in accordance with law. ${ }^{30}$

The constitution also state that 'no person shall be deprived of life or personal liberty saves in accordance with law. ${ }^{31}$

In reality, this most fundamental right is repetitively violated with complete impunity. The government has violated these two articles of the constitution by depriving its citizens of the protection of the law, and of the right to be treated in accordance with the law. 32

Law enforcement agencies have detained victims without a warrant of arrest issued by a court of law, making such arrest illegal. In such cases law enforcement agencies do not

27 Sections 6, 7 \& 12 of the Prevention of Oppression against Women and Children Act, 2000 (Bangladesh).

28 Section 5 of the Prevention of Oppression against Women and Children Act, 2000 (Bangladesh).

29 Listed in Part III of the Constitution of the People's Republic of Bangladesh.

30 Art. 31 of the Constitution of the People's Republic of Bangladesh.

31 Art. 32 of the Constitution of the People's Republic of Bangladesh.

32 Art. 31 of the Constitution of the People's Republic of Bangladesh. 
inform the arrestee of the ground(s) for the arrest, neither do they produce the arrestee before the nearest Magistrate Court; and nor is the arrestee offered the chance to consult with a lawyer. All these elements are in clear violation of the Constitution. ${ }^{33}$

The Universal Declaration of Human Rights of 1948 prohibits arbitrary arrests. ${ }^{34}$ Each enforced disappearance amounts to a violation of right to be safe from illegal arrest. ${ }^{35}$ Bangladesh has also ratified the ICCPR. ${ }^{36}$ According to Articles 2 and 6 of the ICCPR, Bangladesh has the obligation to defend the right to life of its people and to ensure prompt and effective reparation where violations occur.

It is also obliged to bring legislation into conformity with the ICCPR. Under Article 14 , state parties must ensure a fair and public trial for anyone charged with a criminal offense, and such a trial must take place 'without undue delay' The covenant also requires Bangladesh to protect freedom of expression. ${ }^{37}$ Bangladesh is also a state party to the Convention against torture (CAT). Under Article 12, the Bangladeshi government must ensure that any person who alleges he has been subject to torture has the right 'to complain to and to have his case promptly and impartially examined by competent authorities.'

A number of decisions of international human rights bodies have clarified which elements of the phenomenon of enforced disappearances can amount to torture. For example, the European Court of Human Rights in the case of Bazorkina v. Russia ${ }^{38}$ examined an alleged violation of Article 3 ECHR on the prohibition of torture and other degrading or inhuman treatment. The court emphasised that in such a violation, the actual disappearance was not the central criterion; decisive was rather the authorities' reactions and attitude once the matter had been brought to their attention. The court found in the case that the applicant suffered -and continued to suffer- distress and anguish as a result of the disappearance of her son and her inability to learn of his fate. The manner in which

33 Art. 33 of the Constitution of the People's Republic of Bangladesh. The said Article states:

(1) No person who is arrested shall be detained in custody without being informed, as soon as may be

of the grounds for such arrest, nor shall he be denied the right to consult and be defended by a legal practitioner of his choice.

(2) Every person who is arrested and detained in custody shall be produced before the nearest magistrate within a period of twenty four hours of such arrest, excluding the time necessary for the journey from the place of arrest to the court of the magistrate, and no such person shall be detained in custody beyond the said period without the authority of a magistrate.

34 Art. 9 of the Universal Declaration of Human Rights, 1948.

35 Lauterpacht, The Law of Nations and the Punishment of War Crimes, in 21 British Yearbook of International Law (1944), p. 58.

36 On 6 September 2000.

37 Art. 19 of the International Covenant on Civil and Political Rights (ICCPR), 1966.

38 Bazorkina v. Russia, appl. no. 69481/01, 27.07.2006, para. 139. 
her complaints had been dealt with by the authorities had to be considered to amount to 'inhuman treatment' as prohibited by Article $3^{39}$.

It is noteworthy that CAT has become the source of reference for the UN Convention enforced disappearances. One of the features of CAT is the obligation on states parties under Article 4 to criminalise torture in domestic laws with appropriate penalties, and to eliminate safe havens for perpetrators of torture by establishing various types of jurisdictions, including criminal jurisdictions, in accordance with detailed provisions in Articles $5-9$.

The importance of torture as an element of enforced disappearances is that it gives rise to state parties' obligation to criminalise torture. The positive obligations on state parties to prevent, investigate and punish the perpetrators in cases of enforced disappearances and torture are explicitly developed in the jurisprudence of regional human rights courts like the ECtHR and the Inter-American Court on Human Rights. In the case of Velasquez Rodriguez, ${ }^{40}$ the latter court referred to Article 1(1) of CAT and carried out an analysis of the positive obligations it entails. The first obligation on the state party is 'to respect the rights and freedoms' provided for in the Convention, while a second obligation is to 'ensure' every person subject to its jurisdiction the free and full exercise of these rights. The court stated that the states must prevent, investigate and punish any violation of the rights recognised by the Convention and, if possible, attempt to restore the violated rights and provide compensation as warranted for damages resulting from violation.

Similar statements were made by the European Court of Human Rights in the Bazorkina v. Russia case. The Court, like its American counterpart, also stressed the obligation of the authorities to act on their own volition once the matter has come to their attention.

For an investigation ... to be effective it may generally be regarded as necessary for the persons responsible for the investigation to be independent from those implicated in the events. The investigation must also be effective in the sense that it be capable of leading to a determination of whether the force used in such cases is or is not justified and lead to punishment for those who are responsible. This is not an obligation of result, but of means. $^{41}$

The Court noted that delays in the investigation compromised its effectiveness and had a negative impact on the prospect of discovering the truth.

In the Edriss El Hassy v. The Libyan Arab Jamahiriya case, the UN Human Rights Committee concentrated on the obligations on the state party and referred to the impor-

$39 \quad$ Ibid, para. 142.

40 Velasquez Rodriguez vs Honduras, Inter-American Court of Human Rights (IACrtHR (Ser. C) No. 4), 29 July 1988, available at: http://www.refworld.org/docid/40279a9e4.html (Last accessed on 17 December 2015). 
tance of states parties establishing appropriate judicial and administrative mechanisms for addressing the alleged violations under domestic law. It referred to its General Comment No. 31, which states that failure by a State Party to investigate allegations of violations could give rise to a separate breach of the Covenant. The Committee concluded that state parties were duty-bound to conduct thorough investigations into alleged violations of human rights, particularly enforced disappearances and acts of torture and also to prosecute, try and punish those held responsible for such violations.

\section{Conclusion}

The government of Bangladesh is under an obligation to ensure a fair and independent investigation into all cases of disappearance. The government also needs to make clear to its security forces that the state is under an obligation not to torture its citizen under various international instruments. Any criminal offence must be tried through the criminal justice system; the suspect must not be punished by security forces outside the due process of law. In cases of serious human rights violations, the government is under an obligation to take necessary actions to prevent such incidents. Every victim should promptly be produced before a court of law by the concerned law enforcing agency within whose custody he is detained.

The international community should consider the issues of human rights violation and enforced disappearances in diplomatic terms when making any decision about their relation with Bangladesh. Donor agencies should ensure that no person is kidnapped or tortured due to their political identity, and that all persons get equal protection from the law. Bangladesh must be urged to halt the growing phenomenon of enforced disappearances and show its commitment to do so by ratifying the Convention for the Protection of All Persons from Enforced Disappearance without delay, as well as fully implementing it in domestic legislation.

States have committed themselves to ending the practice of enforced disappearance and must take steps to respect, protect and fulfill the rights of individuals not to be subjected to enforced disappearance. Furthermore, states must tackle the issue of impunity and ensure that the perpetrators are brought to justice.

Moreover, to maximise the Convention's preventive effect as well as to offer redress to victims and their families, Bangladesh should also accept the competence of the Committee on Enforced Disappearances to receive complaints from individuals and state parties under Articles 31 and 32 of the Convention.

Another measure that can prevent enforced disappearances and in the longer term eliminate the phenomenon, would be to adopt a long-term and comprehensive plan, which would establish effective training programs for law enforcement and other per- 
sonnel. Civil society actors may also take specific actions to support their recommendations to governments to ratify the Convention. Civil society may participate in drafting and debating national implementing legislation. Civil society members can also provide information in relation to the CED's review of state reports and its other functions under the Convention; they may submit urgent requests for action to clarify the fate and whereabouts of a disappeared person, or submit individual communications on behalf of an individual who claims to be a victim of a violation of the Convention. Women and women's organisations should be particularly encouraged to do so to ensure that gender issues are taken into account and that the process of preparing the implementing legislation is inclusive. Another argument for the involvement of women's organisations is that it is most often men who are subject to disappearance, and female family members then spearhead efforts to obtain justice for their loved ones. 